\title{
Heritage, Reconciliation and Cross-Border Cooperation in Cyprus
}

\author{
Amy Reid
}

\begin{abstract}
Cultural heritage in Cyprus has been a contentious issue throughout the island's tumultuous history. The official partition of the island in 1974, after years of conflict between the Greek and Turkish Cypriot communities, has resulted in the destruction and neglect of heritage sites on both sides of the Cypriot 'border'. However, in recent years there has been an increase in organisations that aim to use heritage as a tool to unite both communities. This contribution examines the work of one such organisation, the Technical Committee on Cultural Heritage in Cyprus (TCCH).
\end{abstract}

\section{KEYWORDS}

borders, culture, heritage, post-conflict, reconciliation, Cyprus

In Cyprus, references to the destruction of cultural heritage remain highly contested. The loss of tangible cultural heritage in the Greek and Turkish Cypriot communities, such as churches and mosques, are both directly and indirectly related to the conflict of the 1960s and 70s. This means that navigating heritage in contemporary Cyprus is fraught with challenges. Furthermore, as a result of the island's division in 1974 and the intractability of the Cyprus dispute, both communities have found that the recovery of their heritage has become a practical impossibility. Despite this, there is cause for optimism. Results from a 2008 survey discovered that 92 per cent of Greek Cypriots and 72 per cent of Turkish Cypriots supported finding joint ways to protect cultural heritage that happens to be under the control of the other community (Kaymak et al. 2008).

Founded in 2008, the Technical Committee on Cultural Heritage in Cyprus (TCCH) is a bicommunal organisation that aims to protect the rich cultural heritage of Cyprus. Since 2011 the TCCH has conserved, structurally supported, physically protected or restored over fifty-five cultural heritage sites of various sizes across the island of Cyprus, with the organisation adopting an approach to the selection of these sites which involves both communities (UNDP 2020). Involved in implementing the aims and objectives of the TCCH is an 
advisory board comprised of a bicommunal team of archaeologists, architects, art historians and town planners.

The overarching aim of this contribution is to explore in greater detail the role of heritage in reconciliation and cooperation on an island marked by violence. Using the TCCH's restoration of the Venetian walls in Nicosia as a case study, I argue that through community engagement and education, the TCCH provides opportunities whereby heritage can be used to encourage meaningful contact between the two communities in Cyprus. This research is informed by ethnographic study of heritage practice in Cyprus, conducted during fieldwork in 2018 and 2019. In addition to this, I also consider in closer detail how Gordon Allport's (1954) intergroup contact theory explains the success of the TCCH in working towards cross-border cooperation in a divided society.

\section{Heritage in the Context of the 'Cyprus Problem'}

Throughout history, Cyprus's geographical proximity to Europe, the Middle East and Africa, meant it was repeatedly conquered by invaders hoping to make use of the strategic benefits of its location. Each of these groups left their own unique mark on both the culture and urban landscape of the island, much of which is still evident in contemporary Cyprus. Greek movement into Cyprus was thought to have begun in $1400 \mathrm{BCE}$ (Hill 2010), whereas the Ottoman invasion of Cyprus in 1570 marked the beginning of the Turkish presence. Throughout this time both communities have been engaged in placemaking activities that have shaped the physical fabric of their communities. For example, the Ottomans in Cyprus converted and modified churches, palaces and other buildings, replicating the urban design of the Ottomans on the mainland (Breen 2019).

Following decades of British rule and several years of anti-colonial uprisings, Cyprus gained its independence in 1960. However, throughout this decade tensions emerged between Greek Cypriots and Turkish Cypriots after proposed changes to the constitution, leading to conflict between the two communities. In 1974, Cyprus was invaded by the Turkish army, following a coup d'état by Greek and Greek Cypriot forces seeking unification with Greece (Ker-Lindsay 2011). Partition of the island was a consequence along with mass migration of Turkish Cypriots to the north and Greek Cypriots to the south. Since 1974 Cyprus has remained divided by the green line, 
which is monitored and patrolled by the United Nations Peacekeeping Force. The impact of a 'border' in this instance had effectively ruptured Cypriot society and has had a profound impact on both communities and their heritage. This dispute between the two ethnic groups is commonly known as 'The Cyprus Problem', encapsulating a complex and intractable conflict, which to date has evaded all peacemaking initiatives. It should be noted that while there exists a wide range of ethnic groups on the island of Cyprus, such as Armenians, Maronites and Latins, the Cyprus Problem focuses primarily on the conflict between the Greek and Turkish Cypriot populations.

In April 2003 the Turkish Cypriot authorities announced that they were ending restrictions on crossing the green line and that Greek Cypriots would be able to cross into the north of the island for the first time since 1974. However, Costas Constantinou et al. (2012) noted that these crossings were both politically and emotionally loaded, with many shocked at the poor condition of heritage sites on the 'other' side. During the conflict of the 1960s and the 1974 invasion, both Greek and Turkish Cypriots experienced the loss of heritage sites, including the destruction and vandalism of churches, mosques, cemeteries and other sites and buildings of importance. However, the division meant that much of this destruction had been invisible due to crossing restrictions. Thus, the reopening of the green line meant that the issue of heritage loss and its subsequent visibility has become another intractable issue within the broader context of the Cyprus dispute. Furthermore, the disruption to each community's sense of belonging as a result of forced displacement was only further exacerbated by the discovery of their lost heritage.

Sara McDowell (2016) acknowledges that heritage is highly politi$\mathrm{cal}$, and in this instance is intrinsically linked with notions of violence, memory and territoriality. This is supported by Constantinou and Hatay (2010: 1614), who report that each side has their own narrative surrounding their lost heritage. They state that Greek Cypriots consider their heritage to be 'plundered, destroyed and made inaccessible by the Turkish Other', which upon the reunification of the island can be rightfully recovered and restored. This remains a highly sensitive issue within Greek Cypriot society. In this instance heritage loss also serves as a reminder of the historical context of the colonial practice of the Ottomans, in which aspects of Cypriot architecture were modified in line with traditional Ottoman design. In comparison, Turkish Cypriots consider that their lost heritage can be 'redeemed through its reconstruction in the abandoned villages of Greek Cypriots in the 
north, which in turn legitimates their Turkification' (Constantinou and Hatay 2010: 1614).

\section{Heritage and Cross-border Cooperation: The Technical Committee on Cultural Heritage}

Recognizing the challenges posed by heritage in Cyprus, the Technical Committee on Cultural Heritage was founded in 2008. Upon its foundation, a preliminary list of forty heritage sites in need of emergency intervention was proposed, with additional sites added to the list as the committee's work progressed. As acknowledged previously, the TCCH have adopted a bicommunal approach to the selection of these sites and monuments. However, particular attention is also given to the archaeological and historical importance of the sites considered for protection. A report on the work of the TCCH (2018) outlined the projects completed between 2008 and 2018, which involved churches, mosques and other archaeological sites on both sides of the green line. These projects range in size from small activities to large ones. Of particular importance is the protection and restoration of the Venetian walls that surround the old town of the capital city Nicosia. As a result of heavy rainfall during 2019 parts of the walls collapsed; in addition the walls had been damaged by vegetation growth resulting from years of neglect. This required urgent intervention by the TCCH to instigate repair work. These renovations were completed in September 2020, receiving attention from Cypriot media sources who highlighted the bicommunal cooperation involved in saving the island's joint cultural heritage (Anonymous 2020).

Alongside the conservation work undertaken by the TCCH, community engagement and education are also significant components of the organisation's mandate. In November 2019, the TCCH conducted a 'heritage away day' workshop to educate participants on the skills used by experts on site to remove vegetation from the Venetian walls. The workshop involved a site visit and those from both communities were encouraged to attend. A significant outcome of initiatives such as these is that local communities are empowered to become more involved in cultural heritage restoration. This also enables quicker responses to monument intervention, which is crucial in building a sustainable future for heritage protection on the island. In July 2019, the TCCH invited children to attend an art and craft event at the Home for Cooperation. The Home for Cooperation is a 
unique community centre located within the buffer zone dividing the capital city of Nicosia. The location of this event is itself significant, as by operating within the buffer zone neither community is limited by the crossing restrictions on each side of the green line, which can often act as a barrier to intergroup contact in Cyprus. During this event, the children crafted their own model of the Venetian walls that surround the city and were taught about the importance of protecting monuments.

A significant measure of the success of the TCCH is its community impact. The TCCH (2018: 5) claim that as a result of their work there was increased visitation to heritage sites, an increase in inter-island exchanges, an increase in the number of religious ceremonies and the involvement of over 7000 Greek and Turkish Cypriots. Furthermore, a perception survey by the $\mathrm{TCCH}^{1}$ demonstrated that 71 per cent believe that cultural heritage monuments can help to improve the confidence and peace-building process between the two communities. Ali Tuncay (2015) also identified that one of the main achievements of the TCCH was the organisation's ability to separate the protection of cultural heritage from the political challenges that are ongoing in Cyprus. However, despite the success of the TCCH, he acknowledged that obstacles remain. The large- and medium-scale projects undertaken by the organisation involve significant costs. The TCCH relies on grants from the EU and other donors, thus delays or other problems with these contributions have a direct impact on the continuation of its work.

\section{Heritage and Reconciliation: An Intergroup Contact Approach}

In Cyprus's case, cultural heritage is part of a wider problem of perpetuating one-sided narratives of the conflict, whereby heritage, memory and identity are often used to demarcate the past. Dacia Viejo-Rose (2013) has noted that heritage plays a crucial role in the reconciliation process in post-conflict societies. She argues that this process can be difficult to navigate, especially in situations involving heritage reconstruction. Furthermore, deciding which heritage sites to rebuild is often laden with difficulty. However, while heritage is often overlooked in the reconciliation process in conflicted societies, it can be a useful tool in helping a society deal with the legacy of their past. This is supported by Audrey Horning et al. (2015: 18), who argue 
that in societies with contested pasts 'archaeological sites, places, or excavations can serve as shared spaces where dialogue is encouraged through informed and participatory investigation'.

In 1954 Gordon Allport developed his theory on intergroup contact. He noted that in order for intergroup contact to reduce prejudice four main conditions must be met. These conditions are: 1) equal status between the groups; 2) common goals; 3) intergroup cooperation and 4) the support of authorities, law or custom. Thomas Pettigrew and Linda Tropp (2005) elaborate further on this, stating that in addition to these four conditions intergroup contact must have 'friendship potential'.

By adopting a bicommunal approach to the TCCH team, community engagement and site selection, the $\mathrm{TCCH}$ ensure that they meet the equal status condition of intergroup contact. Furthermore, making use of 'neutral' spaces such as the Home for Cooperation ensures that much of their work is equally accessible to both communities. There are often cases where people are not able to cross the checkpoints due to political and practical reasons, thus working with the Home for Cooperation removes this barrier to contact. The second condition of effective intergroup contact involves working towards a common goal. In this case, the primary goal of the TCCH and those who engage with the organisation is the protection of endangered cultural heritage on the island. Working towards a common goal encourages people's interest and they therefore become involved because they are invested in the cause.

Often in cases of reconciliation efforts, labelling events as bicommunal can be viewed as quite forced. However, by working towards a common goal people come into contact with those from the other community who have common interests with themselves. Thus, by bonding over common goals they set the scene for future events, collaborations and relationships. The third condition of successful intergroup contact is intergroup cooperation. In this case the TCCH's collaborative approach to community engagement, such as the ongoing dialogue with local communities and more hands-on workshops and events, ensures that they meet this condition. In this case, sharing cultural heritage activities facilitates understanding between the Greek and Turkish Cypriot communities and symbolises mutual respect of the other. Finally, the last condition is the support of authorities, law and custom. In this instance, the TCCH with support from the European Union and the United Nations Development Programme acts as this support. 


\section{Conclusion}

This article has demonstrated the importance of the Technical Committee on Cultural Heritage in facilitating cross-border cooperation in Cyprus. Colin Breen (2019: 34) argues that a better engagement with Cyprus's 'built cultural heritage can provide important insights into the island's history', and that such heritage sites can offer 'more inclusive and non-confrontational discussions on building a more peaceful future'. While the complex and contested nature of heritage in Cyprus can often be difficult to navigate, the $\mathrm{TCCH}$ has demonstrated that heritage can provide an invaluable opportunity for both sides to cooperate over the common goal of protecting the island's shared heritage.

While the primary goal of the TCCH is the protection of the cultural heritage of Cyprus, rather than reconciliation, the concept of intergroup contact underpins the success of the organisation in working with both Greek and Turkish Cypriot communities towards a more peaceful and cooperative future. By working at a grassroots level, the TCCH has more impact within Cypriot society, as they can engage with those most impacted by the legacy of the conflict and the ongoing Cyprus dispute. John Paul Lederach (1997: 81) supports this, highlighting that one of the most significant advantages of working at a grassroots level is that leaders can 'cultivate relationships and pursue the design of social change at a subsystem level, thus helping to make the vertical and horizontal connections necessary to sustain a process of desired change'.

Community engagement is invaluable in countering divisive narratives by using heritage as a tool to encourage meaningful intergroup contact between Greek and Turkish Cypriots. In this instance Cyprus's cultural heritage has become a unifying rather than dividing force. In particular, the education and involvement of children and young people in the activities of the TCCH is crucial within the context of the Cyprus problem. While this demographic is not involved with the structural causes of the conflict, they remain vulnerable to narratives from within their own community that continue to drive division. Furthermore, in Cyprus there are often limited opportunities for young people to come into contact with the other community. Thus, the TCCH's initiatives are crucial in imparting both a trans-generational and cross-community understanding of heritage. 
Amy Reid, Corrymeela Peace and Reconciliation Project, Northern Ireland. E-mail: reid-a37@ulster.ac.uk ORCID: https://orcid.org/0000-0001-8327-3183

\section{Notes}

1. It should be noted that the TCCH do not give any further details on the sample size or demographic composition of this survey. The survey can be found on page five of the following report by the TCCH: www.cy.undp.org/content/ cyprus/en/home/library/partnershipforthefuture/2018-tcch-publication.html (accessed 1 February 2021).

\section{References}

Allport, G. W. (1954), The Nature of Prejudice (Reading, MA: Addison-Wesley).

Anonymous (2020), 'Collapsed Bastion Wall Restored, Bicommunal Technical Committee Says', Cyprus Mail. https://cyprus-mail.com/2020/09/25/collapsed-bastionwall-restored-bicommunal-technical-committee-says/ (accessed 1 February 2021).

Breen, C. (2019), 'The Early Ottomanization of Urban Cyprus', Post-Medieval Archaeology 53, no. 1: 21-37.

Constantinou, C. M. and M. Hatay (2010), 'Cyprus, Ethnic Conflict and Conflicted Heritage', Ethnic and Racial Studies 33, no. 9: 1600-1619.

Constantinou, C. M., O. Demetriou, and M. Hatay (2012), 'Conflicts and Uses of Cultural Heritage in Cyprus', Journal of Balkan and Near Eastern Studies 14, no. 2, $177-198$.

Hill, G. (2010), A History of Cyprus (Cambridge: Cambridge University Press).

Horning, A., C. Breen and N. Brannon (2015), 'From the Past to the Future: Integrating Archaeology and Conflict Resolution in Northern Ireland', Conservation and Management of Archaeological Sites 17, no. 1: 5-21.

Kaymak, E., A. Lordos and N. Tocci (2008), Building Confidence in Peace: Public Opinion and the Cyprus Peace Process (Brussels: Centre for European Policy Studies).

Ker-Lindsay, J. (2011), The Cyprus Problem: What Everyone Needs to Know (Oxford: Oxford University Press).

Lederach, P. J. (1997), Building Peace: Sustainable Reconciliation in Divided Societies (Washington DC: United States Institute of Peace).

McDowell, S. (2016), 'Heritage, Memory and Identity', in B. Graham and P Howard (eds), The Ashgate Research Companion to Heritage and Identity (Aldershot: Ashgate), 37-53.

Pettigrew, T. and L. Tropp (2005), 'Allport's Intergroup Contact Hypothesis: Its History and Influence', in J. F. Dovidio, P. Glick and L. A. Rudman (eds), On the Nature of Prejudice: Fifty Years after Allport (Malden, MA: Blackwell Publishing), 262-277. 
The Technical Committee on Cultural Heritage (TCCH) (2018), '2008-2018: 10 years Working Together for Our Common Heritage'. www.cy.undp.org/content/ cyprus/en/home/library/partnershipforthefuture/2018-tcch-publication.html (accessed 1 February 2021).

Tuncay, A. (2015), 'The Technical Committee on Cultural Heritage from Conflict to Cooperation' www.academia.edu/27279428/The_Technical_Committee_on_ Cultural_Heritage_in_Cyprus_From_Conflict_to_Cooperation (accessed 1 February 2021).

United Nations Development Programme (UNDP) (2020), 'Technical Committee on Cultural Heritage Continue with Safeguarding Efforts during Lockdown'. www. cy.undp.org/content/cyprus/en/home/presscenter/pressreleases/2020/technicalcommittee-on-cultural-heritage-continue-with-safeguard.html (accessed 1 February 2021).

Viejo-Rose, D. (2013), 'Reconstructing Heritage in the Aftermath of Civil War: ReVisioning the Nation and the Implications of International Involvement', Journal of Intervention and Statebuilding 7, no. 2: 125-148. 